in our possession, recognized by honorable warfare, for that purpose. I am for the Union without an $i f$, and regardless of whether slavery stands or falls by its restoration; and in favor of peace on no other terms than the unconditional submission of the rebels to the constituted authorities of the Government of the United States."

It was not probably because the General was not believed to be sound upon the great war issues of that day; not because he did not express his political views in unequivocal English; not because there was any want of appreciation of his valor and efficient services in the field; not because he was not a favorite of the soldiers, that he was not elected. But simply becanse he was not the candidate of the dominent party in the State, and was the candidate of a party which, however correct its intentions at that time, had affiliations with, and contained elements not calculated to inspire confidence in the then state of public feeling, and in consequence failed to rally to itself sufficient strength to make head against the current of exalted patriotic sentiment of the time.

Returning to the field, he performed efficient duty until the spring of 1864, when he was mustered out of the service. The General is now a resident of the city of Des Moines.

EDIToR.

\title{
LAWS RELATING TO THE IOWA STATE HISTORICAL SOCIETY.
}

There are, perhaps, some of the more recently elected members of the State Historical Society, who are not familiar with the earlier legislation concerning it; and there are, no doubt, many of the readers of THE ANNALS, not members of the Society, who have never made themselves acquainted with its exact legal status. We therefore publish in this number the amended law as it read at the time of the meeting of the last (12th) General Assembly; the petition of the Board of Curators of the Society to it, setting forth the accomplishments and needs of the Society; and also their enlightened and liberal enactments relating to it.

AN Aor to provide for annual appropriation for the benefit of a State Historical Society.

[Passed Jamuary 28th, 1857; took effect July 4th, 1857. Lans of Sixth General Assembly, Chapter 203, Page 337.]

Seotion 1959. Be it enacted by the General Assembly of the State of Iowa, That there is hereby annually appropriated until the Legislature shall by law otherwise direct, to a State His31 
torical Society, formed, or to be formed, in connection with and under the auspices of the State University, the sum of five hundred dollars, to be expended by said Society in collecting, embodying, arranging, and preserving in authentic form, a library of books, pamphlets, maps, charts, manuscripts, papers, paintings, statuary, and other materials illustrative of the state of the history of Iowa; to rescue from oblivion the memory of its early pioneers, to obtain and preserve varieties of their exploits, perils and hardy adventures; to secure facts and statements relative to the history, genius, and progress or decay of our Indian tribes; to exhibit faithfully the antiquities, past and present resources of Iowa; also to aid in the publication of such of the collections of the Society, as the Society shall from time to time deem of value and interest; to aid in binding its books, pamphlets, manuscripts, and papers, and in paying other necessary incidental expenses of the Society; but no part of such annual appropriation shall ever be paid for services rendered by the officers to the Society.

Seotion 1960. - It shall be the duty of the Executive Committee of the said State Historical Society of Iowa, to keep an accurate account of the manner of expenditure of the said sum of money hereby appropriated, and furnish the same together with the vouchers thereof;, to the Governor of this State, in the month of December of the year the Legislature shall meet, to be by him laid before the Legislature.

Seotron 1961. There shall be delivered to said Society thirty bound copies of all documents published by order of the State, for the purpose of effecting exchanges with similar Societies in other States, and also fifty bound copies of all such documents, to be transmitted through the medium of the Secretary of said Society, to M. Vattemere, at Paris, in furtherance of his system of international literary exchange.

\section{PETITION.}

To the Honorable the General Assembly of the State of Iowa:

We, the undersigned, your petitioners, members of the Board of Curators of the State Historical Society of Iowa, would respectfully represent that the Society of which we are 
the "Executive Corumittee" is a regularly organized institution, anthorized and established by an act of the Legislature, approved January 28,1857 , with the view of collecting, arranging, and preserving in authentic form, records and incidents connected with the early settlement of Iowa, and for other purposes.

Your petitioners would further represent that the Society has faithfully carried out, so far as their means would permit, the objects for which it was instituted; that it has collected a large number of valuable historical manuscripts, papers, books, and statistical documents, pertaining to the early settlement of the State, that would otherwise have been inevitably lost beyond the hope of recovery; and have also secured from living participants much important history that would have otherwise soon become uncertain tradition, or passed utterly from the knowledge of men; that books, manuscripts, and statistical documents, bearing upon the manners, customs and traditions of the aboriginal inhabitants have been carefully sought, collected, and preserved; also facts relating to the late rebellion, of statistic and incident, which are rapidly gliding out of sight, are being gathered and treasured among its archives; that it has also collected an interesting cabinet of curiosities, consisting of implements and articles which characterize the habits and manners and methods of living of the Indian tribes, and also the vicissitudes of the pioneer citizen; also an extensive cabinet of geological and mineralogical specimens; also very valuable specimens of the natural history of the State, some varieties of which have already passed away before the spread of civilization, and others which are rapidly passing; that the Society issues a quarterly publication of sixty-four pages octavo, of such matter as they deem of present interest; that the publication is intended as one means of collecting valuable historical items, as well also as a vehicle for their promulgation; that the Society is also in receipt of nearly one hundred of the newspapers of the State, weekly, and has reasonable hopes of soon being able to report itself receiving weekly copies of every paper and periodical publish- 
ed within its borders; that a large number of leading papers and periodicals published in other States are also received; that the society is on terms of reciprocal communication and exchange with twenty-six kindred institutions of other States, and with prominent citizens of this country and Europe, from whom it is in constant receipt of books, documents, and specimens; in short, the Society has labored faithfully to "collect, arrange and preserve" the material for every feature of State history from the day of the earliest tread of the white man upon its soil to the present time; and also at the same time to gather much collateral information of a rare, peculiar, or special character relating to history or science, which is beyond the reach of ordinary individual research, and procurable only through the facilities afforded by organized effort; and in these efforts the Society has been successful beyond any reasonable expectation, based upon the means at their command, and is at the present time in a condition of general prosperity respecting the results of its labors.

Your petitioners would further represent that the business of the Society has hitherto been performed by members of the same for a merely nominal compensation, and at the present time without compensation; that the duties of the chief organ of the Society - the Corresponding Secretary - have now attained such magnitude that they can no longer be undertaken gratuitously, a large portion of his time being required for their proper discharge, and the whole of it could and ought to be given to the work in carrying out to the fullest the objects of the organization; also that the Society is now entirely destitute of a place to keep and preserve its large and constantly increasing collections, being only tenants-atwill of the Trustees of the University, in the occupancy of one-half of one upper room, and one room in the basement of the University building, in which latter their property is constantly receiving injury from its unsuitableness, and from these they are liable to be ejected at any time when in the judgment of that Board the small space now occupied is needed for the uses of the school, and it is plain that the 
growing necessities of that Institution will soon require all the available space of all the buildings; that the large number of the newspapers, pamphlets, and documents, which have been for eleven years accumulating, and now on file in the possession of the Society, need to be bound and otherwise protected for preservation, rendering necessary a very considerable immediate outlay; also that the incidental expenses of the Society, to-wit: the procuring and reception of property of historic importance, are quite heavy, and might be increased with rery great profit to the objects of the organization, and through it to the State.

We would also further represent that the quarterly publication, The Annals of Iowa, has not, from the exclusively historical character of its contents, received that popular support necessary to render it self-sustaining, as regards expense; your petitioners, therefore, very respectfully ask appropriations in aid of the Society, as follows, to-wit:

First-An annual appropriation to meet incidental expenses and compensate the working officer of the Society.

Second-A special appropriation to procure a lot and erect a suitable building for the uses of the Society.

SANFORD W. HUFF, Corresponding Secretary, ex-officio Curator, G. W. MCCLEARY, President of Board of Ourators, HENRY MURRAY, M. D., M. W. DAVIS, C. W. HOBART, WILLTAM CRUM, G. W. DODDER, SAMUEL J. HESS, E. M. GRIFFIN, MOSES BLOOM, S. C. TROWBRIDGE, $\quad$ S. S. HOWELL, S. J. KIRKWOOD, WALTER HOYT, R. S. FINKBINE, JOHN P. IRISH, F. H. LEE, WILLIAM VOGT, Board of Curators.

\section{CHAPTER 163.}

As Acr in relation to the State Historical Society.

Whereas, The Iowa State Historical Society was created by an act of the Sixth General Assembly of the State of Iowa, for the purpose of collecting, arranging, and preserving books, pamphlets, maps, charts, manuscripts, papers, paintings, statu- 
ary, and other materials illustrative of the history of this State; and also to preserve the memory of the early pioneers of Iowa, their deeds, exploits, perils and adventures; to secure facts relative to the history of our Indian tribes; to exhibit faithfully the antiquities, and to mark the progress of our rapidly developing Commonwealth; to publish such of the collections of the Society as it shall from time to time deem of value and interest; to bind such publications and other books, pamphlets, manuscripts, and papers, as they may publish or collect; and to aid in all respects, as may be within its province, to develope the history of this State in all its departments; therefore,

Section 1. Be it enacted by the General Assembly of the State of Iowa, For the above purposes, and to aid in defraying the incidental expenses of said Society, including rent and salary of the Secretary, there is hereby appropriated out of any money in the State Treasury not otherwise appropriated, the sum of three thousand dollars per annum for two years, to be drawn on the order, and expended by, the Board of Curators of the said State Historical Society, in such sums as they may from time to time require.

SEc. 2. It shall be the duty of said Society to keep an accurate account of the manner of expenditure of the money hereby appropriated, and furnish a full statement thereof, together with the vouchers, to the Governor of this State, in the month of December preceding the meeting of each session of the General Assembly, to be by him laid before it.

Sec. 3. There shall be delivered to the said Society eighty (80) bound copies of all books and documents published by order of the State, for the purpose of effecting exchanges with similar societies in other States, and for preservation in the library of said Society.

Sec. 4. All acts and parts of acts inconsistent with this act are hereby repealed.

SEC. 5. This act being deemed of immediate importance, shall be in force from and after its publication in the Daily 
State Register and Iowa Evening Statesman, newspapers published at Des Moines.

Approved April 7, 1868.

\author{
STATE OF IOWA, \\ OFFICE OF SECRETARY OF STATE, $\}$ \\ Des Moines, April 11, 1868.
}

I hereby certify the foregoing to be a true copy of the original roll now on file in this office.

Ed Wright, See. of State.

\title{
EDITORIAL REMARKS.
}

\section{CORRESPONDENTS - A CHAPTER ON HISTORY.}

We desire more correspondents for The Ansals. Its publication as a part of the work of the State Historical Society, one of the means of accomplishing its objects, is of the utmost importance; and to gather and preserve within its pages the history of the State, past and present, is a work in which many can join.

There is in every community some person cognizant of the facts of its early settlement, or of important transactions or interesting particulars respecting it, of remote or recent date; which, with a little time, care and labor bestowed, would arrange and put in shape for preservation, and which may prove of great value and interest, enhancing as the date of their occurrence grows more and more remote.

Many people, perhaps most people, are apt to undervalue the historical knowledge which they carry in their memories, or the relics of the past which they have in their possession; and hence the one remains untold and the other unknown; the one passing from the knowledge of men with the passing away of the possessor; the other perishing from sight for want of care, with the valueless articles of the household. The Cabinet Rooms of the Historical Society furnish a place of secure deposit, and protection from injury, for the latter, and its archives, or the pages of THE ANNALS, for the former.

But we desire to speak more particularly respecting the collection of the history of the State, by securing the recollections of those cognizant of its early settlement, or of prominent events or characters connected with it ; or of interests which have influenced its prosperity, or the features of its primitive condition, before it was marred by the hand of civilization. And in these regards there is a wide field and a variety of departments upon which information is sought, and which is now within the knowledge of many in various parts of the State, but by whom it seems to be very reluctantly given up. Among the topics upon which information is sought, is that of the Indian tribes. "Lol the poor Indian!" in another sense than that conveyed by the poet, is ere long to be exclaimed of him. Verily, "the day of their deliverance draweth nigh." So near at hand does it seem, that only a brief time and they will be studied as a people of the past, and investigated with reference to the causes of their rapid extinction. 
Copyright of Annals of Iowa is the property of State of Iowa, by \& through the State Historical Society of Iowa and its content may not be copied or emailed to multiple sites or posted to a listserv without the copyright holder's express written permission. However, users may print, download, or email articles for individual use. 